\title{
Szirtes, George. 2019. The Photographer at Sixteen - The Death and Life of a Fighter. Quercus, London: Maclehose Press. 205 pp.
}

\author{
Reviewed by Dávid Szőke, ${ }^{*}$ University of Szeged
}

George Szirtes's memoir The Photographer at Sixteen, winner of the East Anglia Book Award for Biography and Memoir, long-listed for the Wingate Prize and one of the Times Literary Supplement's Books of the Year, is a moving and absorbing recollection of this poet's maternal heritage. The book's undeniable merit is that with the reconstruction of his mother's figure, Szirtes manages to give meaning to his own Hungarian and Jewish roots, addressing such questions as national and religious identity, displacement, trauma, minority existence and integration in a foreign culture. By doing so, Szirtes powerfully combines historical and autobiographical facts with his artistic imagination, his desire to keep the memory of his mother Magda alive, to recapture her character from fragments of memory, and to ponder about who she was. The figure emerging in this book is of a woman with an iron will and a strong presence, who could be overcome only by her poor health and weak heart. This woman wished to conceal her Jewish identity from her children, and she even made arrangements of a second marriage for her husband once she would be dead. Szirtes's book is a tender portrait of a mother who survived the most terrible event of the twentieth century, the Holocaust, and who fought for the survival of her family, which could only be achieved at the price of their complete abandonment of their original Jewish identity.

After all she had lived through in the Holocaust, at age fifty-one Magda Szirtes took her own life with an overdose of pills. Over four decades after her death, Szirtes ceaselessly attempted to immortalize Magda in his poetry. Nevertheless, it is the form of the memoir that gives the author a better chance to get closer to his parents' past and thus fill in the blank pages of his family history. This authorial intention is supported by the author's choice of delineating his narrative in a reverse order, meaning by proceeding from the present to the past instead of vice-versa. For Szirtes, going backward in time is "like healing a wound, returning to a perfect unwounded beginning where all is innocence and potential" (5). Like in Martin Amis's novel Time's Arrow (1991), or in the movie Memento (dir. Christopher Nolan, 2000), reverse chronology is used to highlight the imprint and burden of trauma on the characters and to head toward the time of innocence, the beginning, out of which the trauma later evolves.

Photographs, says Szirtes, "make a home in memory and settle in like cuckoos, ousting live images, the tiny mental film clips that appear to constitute all we recall of reality, [...] a frozen moment with life flowing on before and after it" (20). These words bear a striking

*beszelo86@gmail.com

(cc) BY

ULLS D-Serle
New articles in this journal are licensed under a Creative Commons Attribution 4.0 International License.

This journal is published by the University Library System of the University of Pittsburgh as part of its D-Scribe Digital Publishing Program and is cosponsored by the University of Pittsburgh Press 
Szőke, Dávid. "Szirtes, George. 2019. The Photographer at Sixteen - The Death and Life of a Fighter. Quercus, London: Maclehose Press. 205 pp." Hungarian Cultural Studies. e-Journal of the American Hungarian Educators Association, Volume 13 (2020) DOI: 10.5195/ahea.2020.412

resemblance to Susan Sontag's observation, in On Photography $(1977,8)$, about the world of images that reaches immortality while real people perish. Szirtes echoes Sontag's view by saying that "[t] he time between old photographs shrinks. Soon there is nothing but photograph" (56). In The Photographer, too, it is the power of the images that creates a link between the present and the past and thus helps the author to invent and reinvent Magda's figure. The book also includes several illustrations, whereby the relation between text and images serves as a form of identity reconstruction through its double rendering of the events in the book.

Using a reverse chronology, Szirtes goes back in time, depicting Magda's early years as a Hungarian-Jewish teenager living in (Romanian) Cluj or (Hungarian) Kolozsvár, in Romania, meaning as a person belonging to two minority groups. Then he moves on to Magda's first job as an apprentice at the age of fourteen at a photographer's studio in Budapest, where during World War II she met her future husband László. He was there on a short leave from labor service in Ukraine and trying to disappear in Budapest. But by the end of June 1944, more than half of the city's Jewish population had been deported, most of them to Auschwitz (145), so it was hardly an ideal hiding place, although even then less harsh than the Eastern-Front service. Eventually László had to return to his unit and he re-united with Magda only after the war. Magda then moved in to live with László's Budapest family and for a short period their shared life there remained unnoticed. But one day, upon returning home, she found herself in an empty flat, and soon she too became one of the deportees from Hungary to Nazi camps. Magda was deported to Ravensbrück, where she spent two months, and then another three in yet another women's camp called Penig, where her physical survival was mainly due to her "superhuman determination to live" (131).

During the liberation of Penig Camp by the United States Army, Magda met a U.S. soldier called George, who offered to take her with him to the U.S., but she turned down his proposal and instead soon reunited with László, who had returned from Ukraine, and soon they were married. Having lived through such horrendous experiences, Magda could never free herself of the trauma of the camps and the loss of her close family. Even worse was her realization that their "perishing was greeted with either indifference or pleasure by those who had previously seemed good-natured and neighbourly" (141). At this point of the narrative, the writer enmeshes imagination and reinvention with historical fact. Despite the fact that already before the war hiding one's Jewish past was not uncommon, Magda's case is unusual in that while she admits that she was in a Nazi camp, she claims that it was for political reasons. All this is even more curious, as in Ravensbrück, while eighty percent of the inmates were political prisoners, there were hardly any Jews among them, whereas Penig was full of Budapest Jews. What makes this line of the narrative striking is Szirtes's tendency to re-embellish the mother's portrayal of her own past, making the myth of her identity even more alive, thus giving the reader some inadvertent hints about the ways and the whys in Magda's biography.

Desperate to re-establish their life among the ruins of Budapest following the Soviet occupation of Hungary, both Magda and László joined the Communist Party, which enabled László to establish a political career as the leader of the Manpower and Statistical Department at the General Mechanical Services Company. With their two sons, George - who was named after Magda's rejected GI suitor - and Andrew, they had a financially secured life, although Magda had her misgivings and reservations about the Party and her husband's position in it. When the growing reign of terror began to be "accompanied by the usual purges, the usual arrival of a car in front of the block and the fear of the knock on the door" (87), with the 1956 Hungarian Revolution getting close to the family's home, and with a bullet bouncing off the ceiling of their 
apartment onto the toy-watch on George's wrist, they made the decision to leave the country. The family crossed the Austrian border on their way to England, leaving all their belongings behind.

Szirtes's depiction of his family's settling in Britain is especially telling. He describes Britain as "damp and inevitably foggy" (75), the British people as "taller than us" (75) and the British upper class as "laconic, undemonstrative, but fastidiously polite" (75). When speaking about his family's integration in the new country, Szirtes argues that his mother "simply found it impossible" (63). In this part the narrative calls to mind the memoirs of some other Hungarian or Central-European Jewish refugees fleeing to England during and after the WWII and the Hungarian Uprising, such as Franz Baermann Steiner, Arthur Koestler and Elias Canetti, all of whom likewise experienced cultural alienation and felt forever rootless in their new country. This notion is underlined by Szirtes in his description of the complex mental and psychological predicament of displacement. For Szirtes, displacement is a wound that "hits you harder than you expect, just when you think you have settled down and become part of the world all over again [...]. Your body is not where your body ought to be [...]. It is as if you had ghosted in but left your soul behind" (16). This portrayal of displacement is very powerful as it explains the moment when one's identity becomes split between two cultures: the one that banished the displaced person without any possibility to return and the one that will always look on the emigrant-turned-immigrant as an outsider.

Added to Magda's feeling of uprootedness was her claimed Christianity and her atheism following her experiences of the Holocaust and her determination to conceal her own and her children's Jewish identity. Szirtes says that, as children, “[w]e had never stepped inside a synagogue, never kept any Jewish holidays or customs: we were not even circumcised" (25). By contrast with Jewish religious issues and identity, keeping the Hungarian spirit in the new country was fundamental, and for this purpose Hungarian food and music served as two strong ties. As Szirtes describes, "Hungarian society in the mid-twentieth century was united in its love of traditional gypsy music [...]. It was a condition of the soul [...], wild, sensuous and freewheeling" (26). Even for Magda, Hungarian gypsy music "signified a freedom of the soul" (p. 25). She listened to and knew many gypsy songs by heart, and music often brought her into tears. Szirtes's account powerfully portrays the generation of Hungarian-Jewish Holocaustsurvivors and then exiles who did their best to maintain their Hungarian identity in transcultural settings while abandoning their Jewishness because of the traumas they had suffered as Jews.

The Photographer at Sixteen is the work of a son trying to recreate the figure of his mother. What shines through in this fascinating and brilliantly written book is the mother's figure of a woman who had an exceptionally strong willpower, which she used to survive and to procure safety for her children. Through Magda's story, the author manages to make sense of his family's past as well as reaffirm his Hungarian and Jewish ties that became loosened by the Holocaust and his years outside Hungary. Thus, the book is a remarkable blend of biographical facts and literary imagination, an act of love for the author's mother and the heritage she stands for, as well as a symbolic quest of an author striving to find meaning in his own complex life and identity. 